\title{
Relationships between interannual variability of glacier mass balance and climate
}

\author{
Roger J. Braithwaite, Yu Zhang \\ School of Geography, University of Manchester, Manchester M13 9PL, England
}

\begin{abstract}
The interannual variability of glacier mass balance is expressed by the standard deviation of net balance, which varies from about \pm 0.1 to $\pm 1.4 \mathrm{~m} \mathrm{a}^{-1}$ for a sample of 115 glaciers with at least 5 years of record. The standard deviation of net balance is strongly correlated with the mass-balance amplitude (half the difference between winter and summer balances) for 60 glaciers, so the amplitude can be estimated from net balance standard deviation for the other 55 glaciers where winter and summer balances are unavailable. The observed and calculated mass-balance amplitudes for the 115 glaciers show contrasts between the Arctic and lower latitudes, and between maritime and continental regions. The interannual variability of mass balance means that balances must be measured for at least a few years to determine a statistically reliable mean balance for any glacier. The net balance of the Greenland ice sheet is still not accurately known, but its standard deviation is here estimated to be about $\pm 0.24 \mathrm{~m} \mathrm{a}^{-1}$, in agreement with other Arctic glaciers. Mass-balance variability of this magnitude implies that the ice sheet can thicken or thin by several metres over 20-30 years without giving statistically significant evidence of non-zero balance under present climate.
\end{abstract}

\section{INTRODUCTION}

Historically, the measurement of glacier mass balance has been concerned with variations in mass balance, and their relationship to parallel climate variations. By contrast, the present paper addresses the variability of mass-balance series, i.e. the likely magnitudes of interannual variations of mass balance, and the way in which these are controlled by climate. Mass-balance variations are illustrated by plotting a series of yearly mass-balance values against time, while the variability is, to a first approximation, expressed by the standard deviation of the mass balance.

Mass-balance data are available in the literature for at least one year for over 200 glaciers (see below). The standard deviations of 115 of these series, with at least 5 years of record, are shown in the histogram in Figure 1. The standard deviation, representing the year-to-year variability of net balance, varies by an order of magnitude from \pm 0.1 to $\pm 1.4 \mathrm{~m} \mathrm{a}^{-1}$. It is important to understand this variability, because the statistical representivity of the mean mass

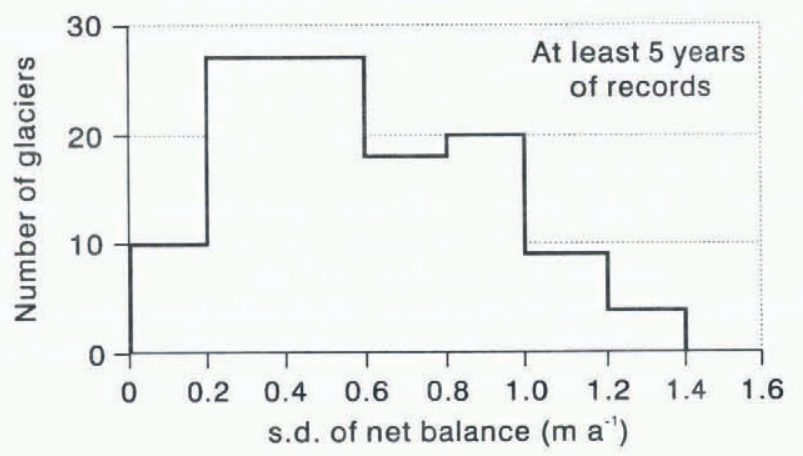

Fig. 1. Standard deviation of net balance for 115 glaciers with at least 5 years of record. balance for a period of a few years depends on the standard deviation. Any putative trend of increasingly negative mass balance has to be detected against the background of yearto-year variations, whose magnitude is expressed by the standard deviation.

More specifically, we became interested in the variability of mass balance when we noticed that glaciers with high mass-balance variability also have a high sensitivity to temperature changes in our degree-day modelling experiments (Braithwaite and Zhang, in press).

\section{GLACIER MASS BALANCE}

The net balance $b_{\mathrm{N}}$ of a whole glacier for any particular year, i.e. the mean specific net balance in $\mathrm{mw}$ w.e., is expressed by separate winter and summer balances $b_{\mathrm{w}}$ and $b_{\mathrm{s}}$ for the year such that:

$$
b_{\mathrm{N}}=b_{\mathrm{w}}+b_{\mathrm{s}} .
$$

Further explanations can be found in Anonymous (1969), while typical field techniques are outlined by Østrem and Stanley (1969) and Ostrem and Brugman (1991). Regular tabulations of mass-balance data have been published by Kasser (1967, 1973), Müller (1977), Haeberli (1985), Haeberli and Müller (1988) and Haeberli and Hoelzle (1993) as part of The Fluctuations of Glaciers series. Another significant source of data, including previously unpublished data from Arctic Canada, Iceland and Svalbard, is Jania and Hagen (1996).

At least one year of mass-balance data is potentially available for over 250 glaciers (Dyurgerov and Meier, 1997; Cogley and Adams, 1998), but most of these records are very short. In the published data tabulations (see above) we could find 115 glaciers with at least 5 years of record, which 
is probably a bare minimum for the assessment of massbalance variability. The number of glaciers is further reduced to 79 by considering only those with separate measurements of winter and summer balance in addition to net balance. Even then, most of these series are short, with a modal length of 5-10 years (Fig. 2). The geographical distribution of these glaciers is also highly biased since separate winter and summer balances are not always measured in Austria or Switzerland, unlike Scandinavia, Canada and the former Soviet Union (FSU) where such measurements are usually regarded as essential. The availability of separate winter and summer balances is further reduced because of errors in some of the tables in Haeberli and Müller (1988) whereby winter and summer balances do not add up to the

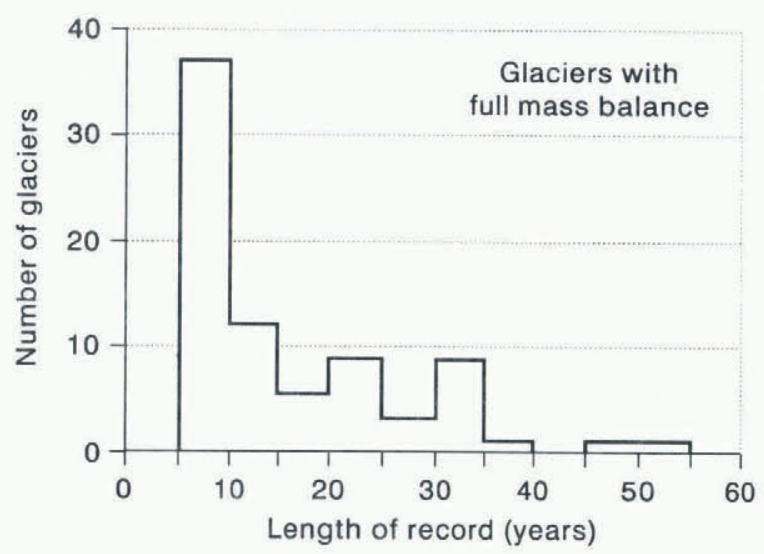

Fig. 2. Length of records for 79 glaciers where full winter, summer and net balances have been measured for at least 5 years.

net balance, hence their exclusion from the analysis here.

An important climatic indicator for a glacier is the massbalance amplitude $\langle\alpha\rangle$ for the period of record, given by

$$
\langle\alpha\rangle=\left(\left\langle b_{\mathrm{w}}\right\rangle-\left\langle b_{\mathrm{s}}\right\rangle\right) / 2
$$

where the angled brackets denote averaging over the period of record. Defined in this way, the average mass balance of the glacier varies throughout the year from winter to summer by $\pm\langle\alpha\rangle$. Substituting for $\left\langle b_{\mathrm{s}}\right\rangle$ gives the amplitude in terms of the mean winter balance:

$$
\langle\alpha\rangle=\left\langle b_{w}\right\rangle-\left\langle b_{N}\right\rangle / 2,
$$

when the glacier is in equilibrium, $\left\langle b_{\mathrm{N}}\right\rangle=0$, and the massbalance amplitude exactly equals the mean winter balance (also the mean summer balance). Even when the glacier is not exactly in equilibrium, the mean net balance is usually small compared with the mean winter balance, so the amplitude is still roughly equal to the mean winter balance.

The mass-balance amplitude, first studied by Meier (1984, 1985), varies by more than an order of magnitude for the 79 measured glaciers, i.e. from nearly $4 \mathrm{~m} \mathrm{a}^{-1}$ for Ivory Glacier (New Zealand) to $<0.4 \mathrm{~m} \mathrm{a}^{-1}$ for glaciers in the Canadian Arctic, with a minimum of $0.14 \mathrm{~m} \mathrm{a}^{-1}$ for the Devon Ice Cap. This variation reflects differences in mean precipitation between different glacier regions, as the amplitude is of the same order of magnitude as the mean precipitation, though not equal to it. For example, not all precipitation on a glacier falls as snow to contribute to the mass balance. Precipitation over glaciers may also be much larger than precipitation in the lowlands, from where most long-term precipitation records come, because of an increase of precipitation with alti- tude, or because of channelling by topography. Glacier precipitation is important because it appears to determine the sensitivity of the mass balance to climate change Oerlemans, 1993). Meier $(1984,1985)$ goes further in suggesting that the mass-balance amplitude is a measure of the long-term mean balance of a glacier.

\section{STANDARD DEVIATION OF MASS-BALANCE SERIES}

The standard deviation of a net balance series $S_{\mathrm{N}}$ is calculated by applying the standard definition of standard deviation to both sides of Equation (1), i.e. forming deviations from the mean, squaring them and then averaging over the period of record. The result is:

$$
S_{\mathrm{N}}^{2}=S_{\mathrm{W}}^{2}+S_{\mathrm{S}}^{2}+2 S_{\mathrm{W}} S_{\mathrm{S}} R_{\mathrm{WS}},
$$

where $S_{\mathrm{W}}$ and $S_{\mathrm{S}}$ are the standard deviations of winter and summer balances, and $R_{W S}$ is the product-moment correlation coefficient between winter and summer balances. According to Equation (4), the variability of net balance can be studied in terms of the variabilities of winter and summer balances, as well as any interaction between winter and summer balance represented by the correlation.

The longest continuous mass-balance series with winter and summer balances is from Storglaciären, northern Sweden, and its data (Holmlund and others, 1996) are used here to illustrate some principles that almost certainly apply to all other glaciers. The net balance (Fig. 3) varies very much from year to year, with a "spikiness" such that similar balances can occur for several years in succession, followed by a sudden large change. The series in Figure 3 is also smoothed with a five-point triangular filter to bring out longer-term trends. It is clear that the net balance is not statistically stationary and there is a slow trend in this particular case towards more positive balances in recent years

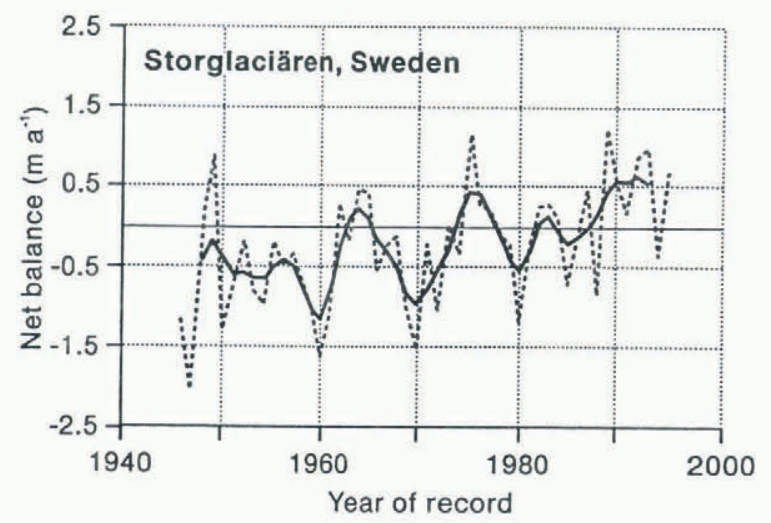

Fig. 3. Variation of net balance of Storglaciären. The dashed line shows measured values and the solid line is smoothed with a five-point triangular filter. Field dala from Holmlund and others (1996).

after substantial losses in the 1950s and 1960s.

Figure 3 shows the historic variations of net balance at Storglaciären, while the variability is expressed by the standard deviations of net balance that are plotted in Figure 4. In this case, the standard deviations refer to overlapping 5 year periods and each point shows what the variability would have been if the net balance had been measured only for the 5 years centred on that point. The "jerkiness" of the variations in Figure 3 is represented by sudden changes in standard deviation in Figure 4. These variations would be 


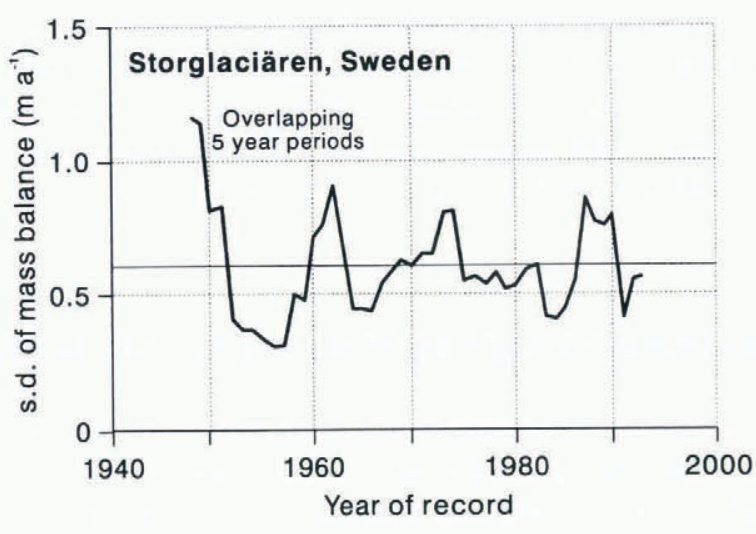

Fig. 4. The standard deviation of overlapping 5 year records of net balance of Storglaciären. Field data from Holmlund and others (1996).

reduced if a longer period were used for calculating the standard deviation, but the 5 year period is chosen because most glacier records are short (Fig. 2). The problem may be exacerbated by the fact that net balance series are generally positively autocorrelated such that successive balance values are not statistically independent. Longer series would certainly be desirable, but, failing that, statistics of short series must be interpreted with suitable caution.

An important concept related to standard deviation is the coefficient of variation, which is simply the standard deviation of any variable, divided by the corresponding mean. Winter and summer balances are inherently one-sided variables (like wind speed, precipitation, runoff, global radiation, etc.), as their variations are bounded by zero. It is a property of such variables that their standard deviations depend on the magnitude of the variables themselves (e.g. as expressed by their means, such that their coefficients of variation tend to be a constant; Yevjevich, 1972). Braithwaite (1982) used a much smaller sample of glaciers than used here to study the relation between standard deviations and means values of winter and summer balances. He found that standard deviations are well correlated with mean values, and suggested a common coefficient of variation for both winter and summer balances. With a much expanded dataset (Table 1), it now appears that summer balances have a larger coefficient of variation than winter balances. Application of Student's $t$ test to the mean values in Table 1 shows that the mean coefficients of variation are unlikely (at $<5 \%$ probability) to be sampled from populations with the same mean values. Summer balance is therefore relatively more variable than winter balance, in contradiction to Braithwaite (1982).

\section{CORRELATION BETWEEN WINTER AND SUMMER BALANCES}

According to Equation (4), the standard deviation of net balance is affected by the correlation between winter and

Table 1. Coefficient of variation for winter and summer balances for glaciers with more than 5 years of record

\begin{tabular}{lcc}
\hline & Winter balance & Summer balance \\
\hline Mean of coefficient & 0.24 & -0.33 \\
s.d. of coefficient & \pm 0.10 & \pm 0.16 \\
Number of glaciers & 60 & 60 \\
\hline
\end{tabular}

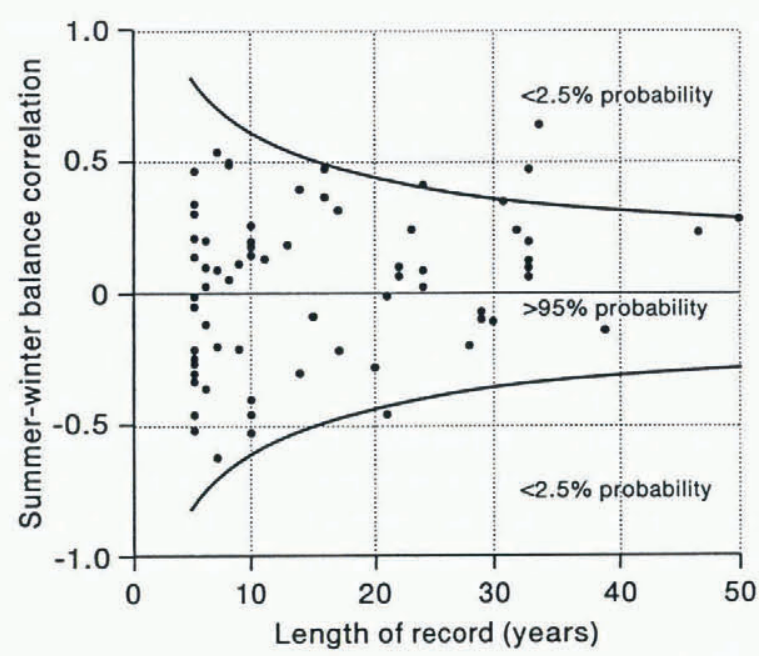

Fig. 5. Correlation between winter and summer balances as a function of length of record for 60 glaciers with more than 5 years of record. The curves enclose all points that could have arisen with $95 \%$ probability from a population with zero correlation.

summer balances. It is highly plausible that there should be a positive correlation between the balances, because high winter accumulation should, all things being equal, favour reduced melting in the following summer due to the effects of a long-lying snow cover with high albedo and low degreeday factor, i.e. a less negative summer balance. However, the calculated correlation coefficients show the widest spread of values with the shortest series (of only 5 years length) and there are generally lower correlations of either sign for longer series (Fig. 5). The curves in Figure 5 enclose the region where there is at least a $95 \%$ probability according to Student's $t$ test (Kreyszig, 1970) that points are sampled from a population with zero correlation between winter and summer balances. As most of the calculated correlations lie within this region, it is difficult to claim any significant correlation (at $<5 \%$ probability) between winter and summer balances. There is, however, a hint of a small positive correlation in the fact that the point distribution in Figure 5 is slightly skewed in the positive direction.

No doubt the expected strong correlation between winter and summer balances is obscured by other factors. For present purposes, the variability of net balance seems to be governed more by the separate variabilities of winter and summer balances than by any interaction between the balances as represented by the correlation $R_{\mathrm{WS}}$ in Equation (4).

\section{MASS-BALANCE VARIABILITY AND CLIMATE}

If the mass-balance amplitude is regarded as a climatic index, mainly representing accumulation or glacier precipitation, it is logical to correlate standard deviations of winter, summer and net balance series with the mass-balance amplitude. As there was some uncertainty about the effects of allowing very short measurement series, the correlations were initially calculated for three different cases: (1) 79 glaciers with at least 5 years of record, (2) 60 glaciers with more than 5 years of record, and (3) 42 glaciers with at least 10 years of record. The results (Table 2) show that the biggest differences in correlation coefficients is between (1) and (2), and that increasing sample sizes to at least 10 years as in (3) does not greatly increase the correlations. The large 
Table 2. Coefficients of determination (square of correlation coefficient) for correlations of winter, summer and net balances with mass-balance amplitude for different subsamples

\begin{tabular}{lcccc}
\hline \multicolumn{1}{c}{ Sample } & Glaciers & $r^{2}$ & $r^{2}$ & $r^{2}$ \\
& & $\begin{array}{l}\text { Winter } \\
\text { balance }\end{array}$ & $\begin{array}{c}\text { Summer } \\
\text { balance }\end{array}$ & Net balance \\
& & & & \\
\hline At least 5 years of record & 79 & 0.63 & 0.45 & 0.64 \\
$\begin{array}{l}\text { More than 5 years of record } \\
\text { At least 10 years of record }\end{array}$ & 60 & 0.72 & 0.58 & 0.79 \\
& 42 & 0.79 & 0.63 & 0.84 \\
\hline
\end{tabular}

difference between cases (1) and (2) cannot be explained by the lower sampling error in 6 year series as compared with 5 year series. More probably, some of the 5 year series are coincidentally affected by other errors. Be that as it may, the following discussion is based on case (2).

The correlations of the standard deviations of winter and summer balances with mass-balance amplitude are illustrated in Figure 6. The former has a somewhat higher correlation and slope, in agreement with the higher coefficient of variation (Table 1). As the standard deviation of net balance is related to the standard deviations of the winter and summer balances, it is hardly surprising that the standard deviation of net balance is also highly correlated with mass-balance amplitude (bottom of Fig. 6). The corresponding regression equations (Table 3 ) show the greatest sensitivity to climate for net balance compared with winter and summer balances. This is consistent with Equation (4), which shows that the variance of net balance $\left({S_{N}}^{2}\right)$ is proportional to the sum of variances of winter and summer balances, both of which are in turn proportional to the massbalance amplitude.

Meier (1984) assumed that long-term balances of glaciers are proportional to their amplitudes. On the face of it, this seems implausible since net balances can be negative or

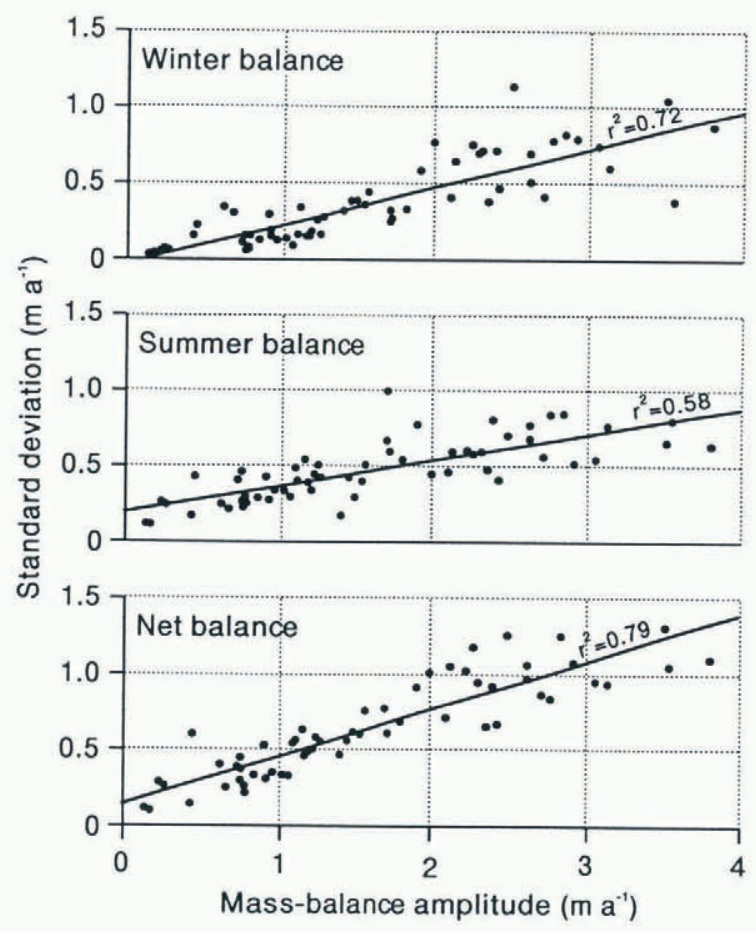

Fig. 6. Correlation of mass-balance standard deviation with mass-balance amplitude for 60 glaciers with more than 5 years of record for winter, summer and net balances.
Table 3. Regression equations linking standard deviation to mean mass-balance amplitude $\langle\alpha\rangle$ for 60 glaciers. Both variables in mwater $a^{-1}$

\begin{tabular}{crrrr}
\hline$Y$ & $\alpha$ & $+\beta \times\langle\alpha\rangle$ & $n$ & $r^{2}$ \\
\hline$S_{\mathrm{W}}$ & -0.03 & $0.25 \times\langle\alpha\rangle$ & 60 & 0.72 \\
$S_{\mathrm{S}}$ & 0.21 & $0.17 \times\langle\alpha\rangle$ & 60 & 0.58 \\
$S_{\mathrm{N}}$ & 0.16 & $0.30 \times\langle\alpha\rangle$ & 60 & 0.79 \\
\hline
\end{tabular}

+ positive, while amplitudes are only positive. However, the sampling standard deviation of the mean mass balance depends on the standard deviation of the mass-balance series, which we show depends on the amplitude. This means that large net balances of either sign are likely to be associated with high mass amplitudes, and that glaciers with low amplitudes are likely to have only small negative or positive net balances.

\section{GUMULATIVE MASS-BALANGE VARIATIONS}

Haeberli and others (1994) note the large year-to-year variations in glacier mass balance and suggest that longer-term trends are best shown by plotting the cumulated massbalance variations against time, i.e. the running sum of the yearly values since the start of record. Such a cumulative balance curve is an example of the double-mass curve (with one variable being time) which is widely used in hydrology (Bruce and Clark, 1966). The cumulative balance curve has two main components: (1) a systematic trend of rising or falling cumulative balance depending on whether the mean balance is positive or negative, and (2) a "random walk" due to cumulated random deviations from the mean balance. Properties of the latter have been extensively studied by Hurst (1956) who proposed a simple formula to describe the range between maxima and minima in such cumulative curves in terms of the length of series. The point is illustrated in Figure 7 which shows cumulative net balance, cumulative mean balance $\left(-0.23 \mathrm{~m} \mathrm{a}^{-1}\right)$ and cumulative net balance deviation from the mean for Storglaciären.

In this case, the cumulative deviations are always negative, so the maximum of the curve remains zero. The minimum of the curve becomes lower (in a negative sense) due

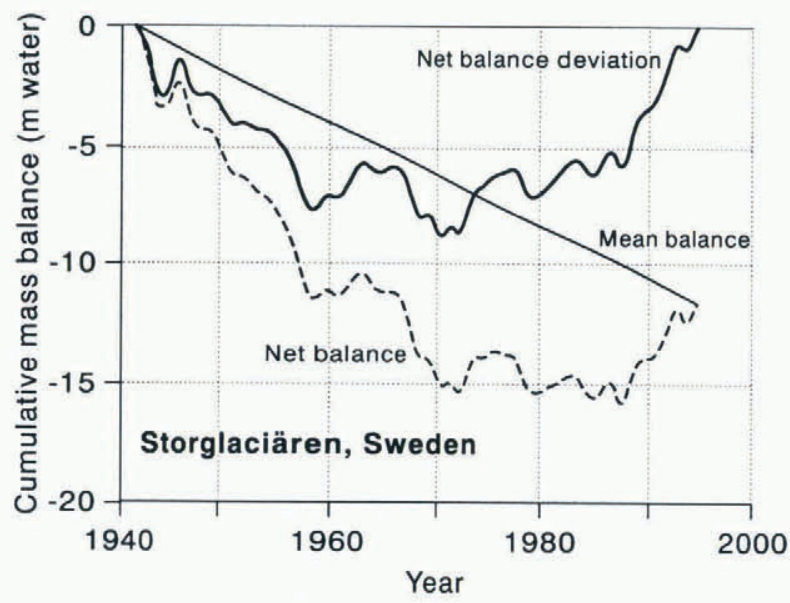

Fig. 7. Cumulative net balance, Storglaciären: cumulative curves of (1) yearly values of net balance, (2) mean balance, and (3) deviation of net balance from the mean. Field data from Holmlund and others (1996). 
to successive "random walks" as the series lengthens, with minima in 1947, 1951, 1954, 1961, 1970 and 1972. According to Hurst (1956), the range $R$ between maximum and minimum of the cumulative curve is given by:

$$
R=S_{\mathrm{N}}(L / 2)^{k},
$$

where $S_{\mathrm{N}}$ is the standard deviation of the net balance, $L$ is the length of series in years and $k$ is an empirical parameter. Hurst (1956) analyzed about 700 long geophysical series (with at least 30 years of record) and found a mean value of 0.72 for $k$ (with standard deviation \pm 0.09 ). The interpretation of Hurst's law is still controversial, as one would expect $k$ to tend towards 0.5 for long random series but for the curve in Figure 7; the $k$ parameter has a value of 0.76 , in reasonable agreement with Hurst's value.

Cumulative mass-balance deviations from 42 other glaciers, with at least 20 years of record, were studied, and close agreement was found between their ranges and those predicted by Hurst's law from the length of series (Fig. 8). We chose not to include series shorter than 20 years in this analysis since we do not know any way of calculating a confidence interval for the range, and we note that Hurst himself used a cut-off of 30 years of record.

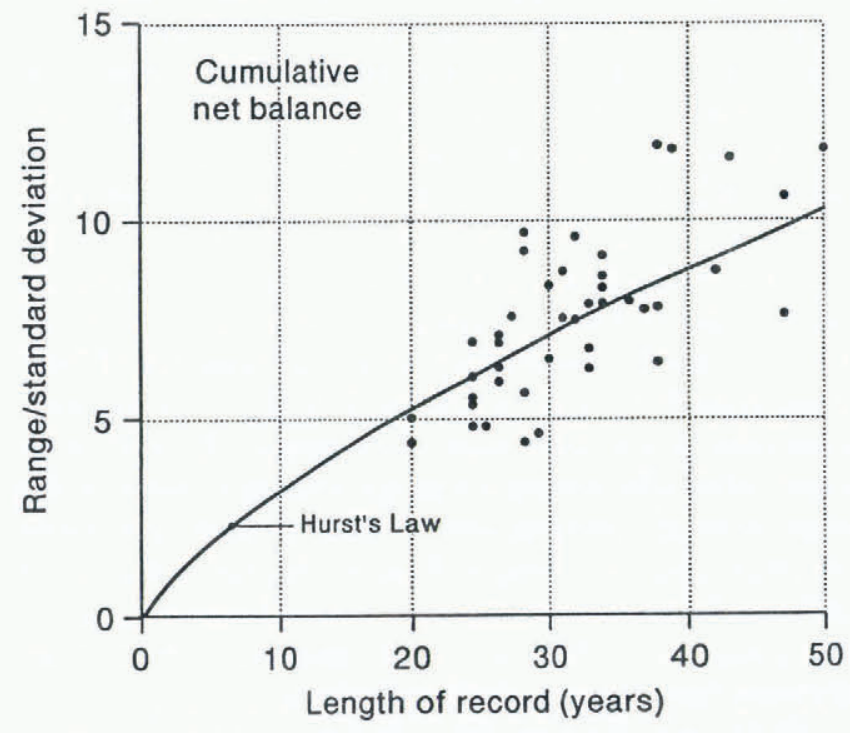

Fig. 8. Relative range of cumulative net balance deviation, i.e. range divided by standard deviation, vs length of series for 43 glaciers with at least 20 years of record. The curve represents Hurst's law.

As the standard deviation $S_{N}$ is controlled by climate, the range in cumulative net balance deviation must also be controlled by climate. For example, the cumulative balance curve of a very maritime glacier (Ålfotbreen, with a massbalance amplitude of $3.5 \mathrm{~m} \mathrm{a}^{-1}$ ) has a range of $8.1 \mathrm{~m}$, but the range for a rather continental glacier (Tsentralnyy Tuyuksu, with an amplitude of $\left.1.2 \mathrm{~m} \mathrm{a}^{-1}\right)$ is only $5.8 \mathrm{~m}$. The range for a subpolar glacier (the Devon Ice Cap, with an amplitude of only $0.14 \mathrm{~m} \mathrm{a}^{-1}$ ) is as low as $0.9 \mathrm{~m}$. These ranges give an idea of the thickness changes that can occur on glaciers even when the mean balance is zero. On maritime glaciers, thickness changes of a few metres spread over several decades need not indicate a statistically significant negative mass balance since the thinning due to negative "random walk" can be compensated by subsequent thickening. The same effect occurs on continental and subpolar glaciers but with a much-reduced range.

\section{GEOGRAPHICAL VARIATION OF MASS-BALANCE AMPLITUDE}

The strong correlation between mass-balance amplitude and standard deviation (Fig. 6) means that the mass-balance amplitude can be estimated from the standard deviation of net balance even if winter and summer balances are not measured separately. In the context of the present study, we have standard deviations for 115 series of at least 5 years in length (Fig. 1) and we use the regression for 60 glaciers in Figure 6 to estimate mass-balance amplitudes for the other 55 glaciers. The results are summarised in Table 4 .

The results in Table 4 are in fair agreement with those given by Meier $(1984,1985)$, although ours are based on longer series. Obviously the averages cannot be very reliable for regions with only a few glaciers or with only short records. It is certainly not claimed that any of the regions in Table 4 is adequately sampled at present, especially as there can be strong gradients within the regions. There are also gradients across large ice masses like the Devon Ice Cap (Koerner, 1966). Nevertheless, two broad patterns can be discerned. The first is the contrast between the relatively arid Arctic regions with low values of amplitude and standard deviation (e.g. the Canadian Arctic (nine glaciers), coastal West Greenland (two glaciers), Svalbard (11 glaciers) and Svernaya Zemlya (one glacier)), compared with the wetter lower latitudes.

The second contrast is between maritime regions, with relatively high amplitudes and standard deviations, and

Table 4. Averages of mass-balance amplitude $\langle\alpha\rangle$ and standard deviation $S_{\mathrm{N}}$ for 27 glacier regions from the World Glacier Inventory (Haeberli and others, 1989)

\begin{tabular}{|c|c|c|c|c|c|c|c|}
\hline \multirow[t]{2}{*}{ No. } & \multirow[t]{2}{*}{ Region } & \multirow[t]{2}{*}{ Country" } & \multirow[t]{2}{*}{$\begin{array}{l}\text { Gla- } \\
\text { ciers }\end{array}$} & \multirow{2}{*}{$\begin{array}{l}\text { Lat. } \\
{ }^{\circ} \mathrm{N}\end{array}$} & \multirow{2}{*}{$\begin{array}{l}\text { Long. } \\
{ }^{\circ} \mathrm{E}\end{array}$} & \multirow{2}{*}{$\begin{array}{c}\langle\alpha\rangle \\
\mathrm{m} \mathrm{a}^{-1}\end{array}$} & \multirow{2}{*}{$\begin{array}{c}S_{\mathrm{N}} \\
\mathrm{ma}^{-1}\end{array}$} \\
\hline & & & & & & & \\
\hline 1 & Canadian Arctic & $\mathrm{CD}$ & 9 & 77 & -86 & 0.30 & 0.27 \\
\hline 2 & Alaska: coast & US & 1 & 60 & -149 & 2.49 & 1.24 \\
\hline 3 & Alaska: interior & US & 1 & 63 & -145 & 1.22 & 0.57 \\
\hline 4 & Coastal N. America & CD/US & 12 & 51 & -125 & 2.30 & 0.73 \\
\hline 5 & Rocky Mountains & $\mathrm{CD}$ & 4 & 49 & -114 & 1.96 & 0.65 \\
\hline 6 & West Greenland & DK & 2 & 64 & -49 & 0.81 & 0.43 \\
\hline 7 & Iceland & IS & 4 & 65 & -18 & 2.51 & 1.01 \\
\hline 8 & Svalbard & $\mathrm{N}$ & 11 & 78 & 14 & 0.86 & 0.32 \\
\hline 9 & N. Scandinavia: coast & $\mathrm{N}$ & 6 & 67 & 15 & 2.67 & 0.92 \\
\hline 10 & N. Scandinavia: interior & $\mathrm{N} / \mathrm{S}$ & 6 & 68 & 19 & 1.50 & 0.56 \\
\hline 11 & S. Norway: coast & $\mathrm{N}$ & 8 & 61 & 7 & 2.50 & 1.03 \\
\hline 12 & S. Norway: interior & $\mathrm{N}$ & 3 & 62 & 8 & 1.24 & 0.57 \\
\hline 13 & The Alps: west & $\mathrm{F}$ & 4 & 46 & 7 & 2.10 & 0.84 \\
\hline 14 & The Alps: central & $\mathrm{CH}$ & 4 & 47 & 9 & 1.95 & 0.75 \\
\hline 15 & The Alps: east & $\mathrm{CH} / \mathrm{A} / \mathrm{I}$ & 11 & 47 & 11 & 1.23 & 0.60 \\
\hline 16 & Caucasus & FSU & 3 & 43 & 42 & 1.41 & 0.47 \\
\hline 17 & East Africa & KN & 1 & 0 & 37 & 1.93 & 0.74 \\
\hline 18 & Svernaya Zemlya & FSU & 1 & 79 & 96 & 0.44 & 0.15 \\
\hline 19 & Polar Urals & FSU & 2 & 67 & 67 & 2.58 & 0.88 \\
\hline 20 & Kamchatka & FSU & 1 & 53 & 159 & 3.58 & 0.9 \\
\hline 21 & Altay (former SU) & FSU & 4 & 50 & 88 & 0.52 & \\
\hline 22 & Alai-Pamir (former SU) & FSU & 1 & 40 & 72 & 1.71 & 0. \\
\hline 23 & Tien Shan (former SU) & FSU & 11 & 43 & 77 & 1.05 & 0.3 \\
\hline 24 & Tien Shan (China) & $\mathrm{CN}$ & 1 & 43 & 87 & 0.50 & 0.31 \\
\hline 25 & Gang Disishan & NP & 2 & 31 & 79 & 0.47 & 0.30 \\
\hline 26 & Himalaya & NP & 1 & 28 & 89 & 0.14 & 0.2 \\
\hline \multirow[t]{2}{*}{27} & New Zealand & NZ & 1 & -43 & 171 & 3.82 & \\
\hline & Total & & 115 & & & & \\
\hline
\end{tabular}

\footnotetext{
Apart from the FSU, countries are denoted by standard automobile abbreviations.
} 
their neighbouring continental regions. Examples of these are the coast-interior contrasts for Alaska (regions 2 and 3), Canada and mainland U.S.A. (regions 4 and 5), northern Scandinavia (regions 9 and 10) and southern Scandinavia (regions 11 and 12). Even the east--west drop in amplitude and standard deviation across the Alps (regions 13-15) may reflect increasing continentality.

The high amplitudes for Kamchatka (region 20) and New Zealand (region 27) no doubt reflect extremely maritime conditions, while generally low amplitudes for regions 21-26 reflect the continentality of the Asian highlands. But here again, the drop in mass-balance amplitude from a relative high in the Alai-Pamir $\left(1.7 \mathrm{~m} \mathrm{a}^{-1}\right.$ in region 22$)$ across the former-Soviet Tien Shan $\left(1.0 \mathrm{~m} \mathrm{a}^{-1}\right.$ in region 23$)$ to a low in the Chinese Tien Shan $\left(0.5 \mathrm{~m} \mathrm{a}^{-1}\right.$ in region 24) hints at a regional contrast. This probably reflects the west-east variation in annual precipitation from 1.5 to only about $0.3 \mathrm{ma}^{-1}$ across the Tien Shan. The relatively high mass-balance amplitude for the two glaciers in the polar Urals $\left(2.58 \mathrm{~m} \mathrm{a}^{-1}\right)$ might be the result of local topographic enhancement of regional precipitation, which is only of the order of $1 \mathrm{~m} \mathrm{a}^{-1}$ (Grosval'd and Kotlyakov, 1969).

\section{MASS-BALANCE MONITORING}

One of the most important problems for mass-balance glaciology, after more than 50 years of hard work, is the sad fact that many glacierized regions of the world remain unsampled, or only poorly sampled. There are slight prospects of getting further highly detailed mass-balance measurements for at least 5 years, from the remoter areas of South America (Andes and Patagonia), Asia, the Arctic and the Antarctic Peninsula. However, the year-to-year variability of mass balance has implications for the interpretation of whatever short series may become available in the future for remoter areas. For example, the null hypothesis for any short-term study would have to be that the glacier has zero balance under present climate, and the observed mean balance must be tested against this hypothesis using Student's t-test, which involves the standard deviation of the mass balance. In the case of a very short series of measurements, it might be better to use a regional estimate of standard deviation, as in Table 4, rather than the actual standard deviation of the short measured series which will be subject to excessive sampling errors.

Repeated mass-balance measurement by field parties over several decades seems a laborious way to detect the effects of climate change on ice masses. As a more economical alternative, useful information might be obtained by remote sensing or by reconnaissance methods, but these would have to be carefully planned to achieve the best results. In this case, the variability of the mass balance in the field area would have to be estimated to ensure that possible changes are within the limits of detectability of the chosen method. For example, it is tempting to measure mass changes of the larger ice caps in the Arctic by repeated airborne laser altimetry with an accuracy of \pm 0.1 to $\pm 0.2 \mathrm{~m}$ (Krabill and others, 1995). However, as the mass-balance variability of these ice bodies is small, surveys should only be repeated at long enough intervals to allow small annual changes to accumulate.

\section{APPLICATION TO GREENLAND ICE SHEET}

The present results also have implications for the Greenland ice sheet, whose state of balance is not presently known (Braithwaite, 1994, 1996). The field measurements do not cover the whole ice sheet in enough detail for a conventional mass-balance estimation, and recent measurements of thickness changes by satellite radar altimetry (Zwally, 1989) seem controversial (Douglas and others, 1990; Zwally and others, 1990; Van der Veen, 1993; Braithwaite, 1994; Wingham, 1996). However, the standard deviation of the (unknown) net balance of the Greenland ice sheet can be estimated from the mean accumulation, $0.3 \mathrm{~m} \mathrm{a}^{-1}$ (Ohmura and Reeh, 1991), and the regression equation in Table 3 . The resulting standard deviation is $\pm 0.24 \mathrm{~m} \mathrm{a}^{-1}$, which is in good agreement with Arctic glaciers like White Glacier, Axel Heiberg Island and the northwest Devon Ice Cap.

The standard deviation is then substituted into Hurst's law (Equation (5)) to estimate the range in cumulated mass balance ( $m$ water) for the Greenland ice sheet as a function of length of period (Table 5). The equivalent thickness change in $\mathrm{m}$ firn is obtained by applying a suitable firn density for central Greenland $\left(450 \mathrm{~kg} \mathrm{~m}^{-3}\right)$. This thickness change will occur as either a thickening or thinning in the first part of the period, followed by an equal and opposite change in the later part of the record, even when there is no net change over the whole period, i.e. the ice sheet has zero mass balance. If we take a period of 20-30 years as representing "present climate", we have to conclude that thickness changes of several metres (of either sign) can be observed without necessarily being evidence of a greatly negative or positive mass balance under present climate. The Greenland ice sheet might therefore have to be monitored over many decades to detect unambiguous evidence of either thinning, due to increased melting, or thickening, due to increased accumulation.

Table 5. Thickness changes of the Greenland ice sheet caused by the Hurst effect

\begin{tabular}{cccc}
\hline $\begin{array}{c}\text { Length of period } \\
\text { years }\end{array}$ & $\begin{array}{c}\text { Range } \\
\text { m water }\end{array}$ & $\begin{array}{c}\text { Firn density } \\
\mathrm{kg} \mathrm{m}^{-3}\end{array}$ & $\begin{array}{c}\text { Thickness change } \\
\mathrm{m} \text { firn }\end{array}$ \\
\hline 5 & 0.47 & 450 & \pm 1.04 \\
10 & 0.78 & 450 & \pm 1.73 \\
15 & 1.04 & 450 & \pm 2.32 \\
20 & 1.29 & 450 & \pm 2.86 \\
25 & 1.52 & 450 & \pm 3.37 \\
30 & 1.73 & 450 & \pm 3.85 \\
\hline
\end{tabular}

\section{SUMMARY AND CONGLUSIONS}

The year-to-year variability of glacier mass balance is expressed by the standard deviation of net balance. Over a sample of 115 glaciers with at least 5 years of mass-balance record, the standard deviation varies from about \pm 0.1 to $\pm 1.4 \mathrm{~m} \mathrm{a}$. The standard deviation of net balance is strongly correlated with the mass-balance amplitude, which varies by more than an order of magnitude from about $4 \mathrm{ma}^{-1}$ (very maritime glaciers) to only $0.14 \mathrm{~m} \mathrm{a}^{-1}$ (Arctic glaciers).

Long-term trends in mass balance are often illustrated by the plotting of cumulated mass-balance variations against time in a double-mass curve. The cumulative balance curve 
has a "random walk" component whose range is determined by the standard deviation of the mass balance according to Hurst's law. As the standard deviation is controlled by climate, the range in cumulative net balance is also controlled by climate such that larger thickness changes occur on maritime glaciers than on Arctic or continental glaciers.

The strong correlation between mass-balance amplitude and standard deviation means that mass-balance amplitude can be estimated from the standard deviation of net balance for those glaciers where winter and summer balances are unmeasured. Geographical variations of mass-balance amplitude show two main contrasts: (1) between the relatively arid Arctic and wetter lower latitudes, and (2) between maritime regions and their neighbouring continental regions. There are also variations across mountain ranges like the Alps and the Tien Shan, which probably reflect relative variations in continentality.

The variability of mass balance means that mass balances must be measured for at least a few years to determine a statistically reliable mean balance for any glacier. For example, the standard deviation of the net balance of the Greenland ice sheet is estimated to be about $\pm 0.24 \mathrm{~m} \mathrm{a}^{-1}$, in good agreement with other Arctic glaciers. A mass-balance variability of this magnitude implies that the thickness of the Greenland ice sheet can change by several metres over a period of 20-30 years without necessarily being evidence of a greatly negative or positive mass balance under present climate.

\section{ACKNOWLEDGEMENTS}

This study was made as part of the Climate and Environment Programme, European Union, under grant number ENV4-CT95-0124 to the University of Manchester, co-ordinated by the Climatic Research Unit, University of East Anglia.

The mass-balance data for this study are mainly taken from The Fluctuations of Glaciers series published by the World Glacier Monitoring Service (WGMS, Zürich, Switzerland), supplemented by other published data compilations. The data were collected over many years by many individual scientists and organisations, and have been made freely available to the international community for further study and synthesis. Such openness and generosity with hardwon data are in the highest traditions of science.

\section{REFERENCES}

Anonymous. 1969. Mass-balance terms. F. Glaciol., 8(52), 3-7.

Braithwaite, R.J. 1982. A simple model of runoff from ungauged basins in West Greenland. Grönlands Geol. Undersögelse Rapp. 111.

Braithwaite, R.J. 1994. Thoughts on monitoring the effects of climate change on the surface elevation of the Greenland ice sheet. Global and Planetary Change, 9 (3-4), 251-261.

Braithwaite, R. J. 1996. Mass balance of the Greenland ice sheet: a century of progress but there is still much to do. Z. Gletscherkd. Glazialgeol., 31, Part $1,1995,51-56$

Braithwaite, R. J. and Y. Zhang. In press. Sensitivity of mass balance of five Swiss glaciers to temperature changes assessed by tuning a degree-day model. J. Glaciol.

Bruce, J. P. and R. H. Clark. 1966. Introduction to hydrometeorology. Toronto, Pergamon Press.

Cogley, J. G. and W. P. Adams. 1998. Mass balance of glaciers other than the ice sheets. f. Glaciol., $44(147), 315-325$.

Douglas, B. C., R. E. Cheney, L. Miller, R.W. Agreen, W. E. Carter and
D. S. Robertson. 1990. Greenland ice sheet: is it growing or shrinking? Science, 248(4953), 288.

Dyurgerov, M. B. and M.F. Meier. 1997. Mass balance of mountain and subpolar glaciers: a new global assessment for 1961-1990. Arct. Alp. Res., 29 (4), 379-391.

Grosval'd, M. G. and V. M. Kotlyakov. 1969. Present-day glaciers in the U.S.S.R. and some data on their mass balance. J. Glaciol., 8 (52), 9-22.

Hacberli, W., comp. 1985. Fluctuations of glaciers 1975-1980 (Vol. IV). Paris, International Commission on Snow and Ice of the International Association of Hydrological Sciences/UNESCO.

Haeberli, W. and M. Hoelzle, comps. 1993. Fluctuations of glaciers 1985-1990 (Vol. VI). Wallingford, Oxon, IAHS Press; Nairobi, UNEP; Paris, UNESCO.

Haeberli, W. and P. Müller, comps. 1988. Fluctuations of glaciers 1980-1985 (Vol. V). Wallingford, Oxon, IAHS Press; Nairobi, UNEP; Paris, UNESCO.

Haeberli, W., H. Bösch, K. Scherler, G. Ostrem and C. C. Wallén, eds. 1989. World glacier inventory: status 1988. Wallingford, Oxon, IAHS Press; Nairobi, GEMS-UNEP; Paris, UNESCO.

Haeberli, W., M. Hoelzle and H. Bösch. eds. 1994. Glacier Mass Balance Bulletin. Bulletin. No. 3 (1992 1993). Zürich, IAHS ICSI), World Glacier Monitoring Service; Nairobi, UNEP; Paris, UNESCO.

Holmlund, P., W. Karlén and H. Grudd. 1996. Fifty years of mass balance and glacier front observations at the Tarfala Research Station. Geogr. Ann., 78A (2-3), 105-114.

Hurst, H. E. 1956. Methods of using long-term storage in reservoirs. Proc. Inst. Civ. Eng., 5, $519-590$.

Jania, J. and J. O. Hagen, eds.. 1996. Mass balance of Arctic glaciers. Sosnowiec/ Oslo, International Arctic Science Committee. Working Group on Arctic Glaciology. (IASC Report 5.)

Kasser, P. 1967. Fluctuations of glaciers 1959-1965/Vol. I 7. Paris, International Commission of Snow and Ice of the International Association of Scientific Hydrology/UNESCO.

Kasser, P., comp. 1973. Fluctuations of glaciers 1965-1970 [ Vol. II]. Paris, International Commission on Snow and Ice of the International Association of Hydrological Sciences/UNESCO.

Koerner, R. M. 1966. Accumulation on the Devon Island ice cap, Northwest Territories, Canada. 7. Glaciol., 6(45), 383-392.

Krabill, W. B., R. H. Thomas, C. F. Martin, R. N. Swift and E. B. Frederick. 1995. Accuracy of airborne laser altimetry over the Greenland ice sheet. Int. J. Remote Sensing, 16 (7), 1211-1222.

Kreyszig, E. 1970. Introductory mathematical statistics. New York, John Wiley and Sons.

Meier, M. F. 1984. Contribution of small glaciers to global sea level. Science, 226 (4681), 1418-1421.

Meier, M. F. 1985. Mass balance of the glaciers and small ice caps of the world. In Glaciers, ice sheets, and sea level: effect of a $\mathrm{CO}_{2}$-induced climatic change. Report of a Workshop held in Seattle, Washington, September 13-15, 1984. Washington, DC, U.S. Department of Energy. Office of Energy Research, 139-144. (Attachment 6, Report DOE/ER/60235-1.

Müller, F., comp. 1977. Fluctuations of glaciers 1970-1975 (Vol. III). Paris, International Commission on Snow and Ice of the International Association of Hydrological Sciences/UNESCO.

Oerlemans, J. 1993. Modelling of glacier mass balance. In Peltier, W. R., ed. Ice in the climate system. Berlin, etc., Springer-Verlag, 101-116. (NATO ASI Series I: Global Environmental Change 12.)

Ohmura, A. and N. Reeh. 1991. New precipitation and accumulation maps for Greenland. J. Glaciol., 37 (125), 140-148.

Ostrem, G. and M. Brugman. 1991. Glacier mass-balance measurements. A manual for field and office work. Saskatoon, Sask., Environment Canada. National Hydrology Research Institute. (NHRI Science Report 4. )

Ostrem, G. and A. D. Stanley. 1969. Glacier mass balance measurements; a manual for field and office work: a guide for personnel with limited backgrounds in glaciology. Ottawa, Ont., Department of the Environment. Inland Waters Branch. (IWB Reprint Series 66.

Van der Veen, C. J. 1993. Interpretation of short-time ice-sheet elevation changes inferred from satellite altimetry. Climatic Change, 23 (4), 383-405.

Wingham, D. J. 1996. Elevation change of the Greenland ice sheet and its measurement with satellite radar altimetry. In Wadhams, P., J. A. Dowdeswell and A. N. Schofield, eds. The Arctic and environmental change. Amsterdam, etc., Gordon and Breach Publishers, 135-146.

Yevjevich, V. 1972. Probability and statistics in hydrology. Fort Collins, CO, Water Resources Publications.

Zwally, H.J. 1989. Growth of Greenland ice sheet: interpretation. Science, 246(4937), 1589-1591.

Zwally, H.J., A. C. Brenner, J. A. Major, R. A. Bindschadler and J. G. Marsh. 1990. Greenland ice sheet; is it growing or shrinking? Response. Science, 248 (4953), 288-289. 